\title{
Data Collection Instrument in Designerly Intuition Study
}

\author{
Natrina Mariane P. Toyong, Shahriman Zainal Abidin, S'harin Mokhtar \\ Faculty of Art \& Design, Universiti Teknologi MARA, 40450, Shah Alam, Malaysia \\ natrinatoy@uitm.edu.my, shahriman.z.a@uitm.edu.my, sharin2066@uitm.edu.my \\ Tel of 1st Author: +60162060081
}

\begin{abstract}
The paper discusses the development of interview and focus group instruments to uncover the intuition occurrences in Designerly practices. The two data collecting method forms data source triangulation through in-depth interviews of eight experts and eight senior-level designers with four focus group sessions involving thirty-two novice-level designers. The instrument development took into consideration its reliability and validity for the triangulation analysis stage to follow. The result from four pilot interviews and one focus group discussion provides recommendation and refinement for the researcher's guide as well as various data collection methods within the Design and Designerly research area.
\end{abstract}

Keywords: Designerly, Intuition, Design Thinking, Research Instrumentation

eISSN: 2398-4287@ 2021. The Authors. Published for AMER ABRA cE-Bs by e-International Publishing House, Ltd., UK. This is an open access article under the CC BYNC-ND license (http://creativecommons.org/licenses/by-nc-nd/4.0/). Peer-review under responsibility of AMER (Association of Malaysian Environment-Behaviour Researchers), ABRA (Association of Behavioural Researchers on Asians/Africans/Arabians) and cE-Bs (Centre for Environment-Behaviour Studies), Faculty of Architecture, Planning \& Surveying, Universiti Teknologi MARA, Malaysia.

DOI: https://doi.org/10.21834/ebpj.v6iSI5.2925

\subsection{Introduction}

There has been a significant increase in empirical studies on intuition in the creativity world, especially with understanding it philosophically in the Art field. However, within the Design field, which is increasingly technique, framework and method-driven, the topic of intuition leave additional room for discussion. The mainstream narrative on intuition often border around the path of divinity, spirituality, psychoanalysis, and at times loosely used to describe sudden stroke of genius moments, which implies its non-reliance on anything concrete. In many professional fields, it is acknowledged that the reason for its claim to be unscientific can be attributed to the strict boundary set between the concept of intuition and reason (Welling, 2005), which separates it the thinking the sudden strokes of geniuses. This common misconception on the nature of intuition is what makes it appear to be an intuitive ability that is not easily trained and lin some instances, suggesting that a person requires to be gifted to have an intuitive mode of functioning (Abidin, Bjelland, and Øritsland, 2008). This paper argues this to bring to the fore the importance of intuition as an essential humanistic skill through two qualitative inquiry modes. Reviewing the basic construct of existing intuitive studies from other fields will establish a basic framework in which Designer intuition can be uncovered. In turn, it will develop a model to fit into the current design ecosystem, leading to a qualitative inquiry design, which applies to the in-depth interview and focus group discussion as data collection methods.

\author{
Nomenclature \\ A \\ Designerly \\ B Design Research
}

eISSN: 2398-4287C 2021. The Authors. Published for AMER ABRA cE-Bs by e-International Publishing House, Ltd., UK. This is an open access article under the CC BYNC-ND license (http://creativecommons.org/licenses/by-nc-nd/4.0/). Peer-review under responsibility of AMER (Association of Malaysian Environment-Behaviour Researchers), ABRA (Association of Behavioural Researchers on Asians/Africans/Arabians) and cE-Bs (Centre for Environment-Behaviour Studies), Faculty of Architecture, Planning \& Surveying, Universiti Teknologi MARA, Malaysia.

DOI: https://doi.org/10.21834/ebpj.v6iSl5.2925 


\subsection{Literature Review}

\subsection{Intuition And Designerly Thinking}

Dörfler and Stierand (2016) summarize the intuitive process as being rapid, instantaneous and spontaneous and a logical result in intuition that is defined as tacit, holistic or gestalt, resulting in confident intuitors. Intuition studies have covered various domains to characterize and uncover the phenomenon in various fields. Notably, Sinclair (2011) has conceptualized an integrated framework of intuition, outlining three processing types: inferential processing, holistic processing, and nonlocal processing. Eling, Griffin and Langerak (2014) have offered a framework for situations when intuition can be practical, specifically in the fuzzy front end of new product development. It is proven that the use of intuition in both fuzzy front-end generation and evaluation decisions increases the creativity of the new product concept. The study identifies the two processes of intuition; making new associations and matching complex patterns.

Welling (2005) has summarized intuition into five modes of knowledge representation; Detection Phase, Dichotomic Awareness Phase, Related object phase, metaphorical solution phase and explicit verbal understanding phase. There is also empirical evidence that allows measurement for intuition. Pretz, Brookings, JCarlson, Humbert, Roy, Jones and Memmert (2014) introduced and tested the measurement of the three types of intuition (TIntS) which are holistic intuition, inferential intuition and affective intuitions. More recently, many studies can support the narrative that the act of intuiting is independent of the analysis process (Wang, Highhouse, Lake, Petersen and Rada, 2017; Alós-Ferrer and Hügelschäfer, 2016; Mohamed Kamil, and Abidin, 2015).

The association between intuition and creativity has been established in many studies. Bohart (1999) argues that creativity arises from tacit, intuitive knowing as a person continuously create new meaning in everyday life. The paper also concludes that even automated and proceduralized action such as driving and athleticism is, in fact, flexible and creative in nature, where experiences are rarely identical. The instantaneity of intuitive insight and judgement is a contributor to creativity (Stierand and Dörfler, 2016; Zainal Abidin, Anwar, and Rahim, 2020). The rapidness and directness of 'knowing' relate to creativity at a varied level. A particular form of extremely original creativeness is when the thoughts are free from any previously learned schema, knowing without knowing how the thought came to be (Lee and Chien, 2018). A study on intuitive functions in design by Çizgen and Ulusu Uraz (2019) characterizes it against existing theories to identify four related 'Design Moves'; direct matching, associative matching, total synthesis and radical synthesis.

As presented by Cross (2006), the term Designerly implies that 'Designerly ways of knowing' should be the third knowledge that must be introduced as general education in schools, alongside the sciences and humanities. This third knowledge area differs from the sciences and humanities in that it deals with design-specific things to know, ways of knowing and ways to know them (Chumiran, Abidin, and Mohamed Kamil, 2020; Zainal Abidin, Sigurjónsson, Liem, and Keitsch, 2008). The delicate area of this knowledge lies within the constructivist paradigm in which the learning process is active in nature and knowledge recipients create their subjective representation of reality. While discussing the constructivist paradigm, Schön (1983) characterized the term "reflective practice". The discussion proposed searching for the epistemology of practice specific to the artistic that deals with uncertainty, instability, uniqueness, and value conflict. The distinction is important given the nature of design practice, where results do not require it to be repeatable or copied (Mohamed Kamil, Abidin, and Hasdinor Hassan, 2018).

\subsection{Instrumentation Design}

Ness (2015) recognizes data triangulation to get to data saturation by uncovering different levels and perspectives of the same phenomenon. The view supports Golafshani (2003), which conceptualizes reliability and validity as trustworthiness, rigour and quality in the qualitative paradigm. Therefore, this Designerly Intuition study employs a quota sampling of three-expertise levels of the respondent to achieve this. The identification of the correct sampling for data coverage is adapted from the definition by Liem, Abidin, and Warell (2009) derived from Popovic (2004). Cross (2001) acknowledges the different cognition functions of creative novice versus experts in approaching a design task. This difference will be good insights in understanding the extent of intuitive thinking applied to their approaches and whether it is all attributed to intuitiveness (Abidin, Christoforidou, and Liem, 2009; Abidin et al., 2016). At the same time, it is also argued that 'productive design behaviour seems to be associated with frequent switching of types of cognitive activity (lbid).

The study will adopt one low-level expertise group and two higher-level expertise. They consist of Novice (student, educator or practitioner with less than five years working experience in the industry), Senior (educator or practitioner 8/10 to 15/18 years working experience in the industry) and Expert (educator or practitioner with more than 18 years working experience in the industry). The sampling for practitioners will consider two levels of expertise to allow for more thorough insights to be compared to the novices. Studies from analogous fields have examined the comparison of intuition versus analytical role between experienced senior and less experienced senior (Wolfe, Christensen, and Vandervelde, 2019; Abidin, Warell, and Liem, 2011).

Table 1. Quota Sampling of Respondents based on Level of Expertise

\begin{tabular}{lll}
\hline Level of Design Expertise & In-depth Interview & Focus Group Discussion \\
\hline $\begin{array}{l}\text { Expert (practitioner) } \\
\text { More than } 18 \text { years of experience }\end{array}$ & 8 & - \\
$\begin{array}{l}\text { Senior (practitioner) } \\
8 / 10 \text { years to } 15 / 8 \text { years }\end{array}$ & 8 & - \\
$\begin{array}{l}\text { Novice } \\
\text { Less than five years }\end{array}$ & - & $8 \times 4$ session $=32$ \\
\hline
\end{tabular}




Total 48 Respondents

Intuition as a research area is not free of biases. One of the critical considerations is limiting the number of variables in a study by identifying the closest set of intuitiveness for the designer culture. In other words, respondent screening criteria should be as homogenous to the specific field as possible (Gasparatou, 2010). In this case, the study screens respondents Novice-level respondents studying a bachelor of Industrial Design and senior and expert practitioners who graduated with at least a bachelor degree in Industrial Design. The chosen common theme used in the research: FUTURE WORKSPACE FOR (INDUSTRIAL) DESIGNER IN THE YEAR 2050, justifies the shared traits of all 48 respondents. Based on past studies, to uncover intuitiveness, the discussion must accommodate room for familiarity, comparable subject matter, and room for emotive affect to reasoning. Befitting this, the theme is familiar for both novice and practitioner, even if it requires predictive reasoning.

The in-depth interview and focus group research is designed to accommodate reflective sessions to trigger intuitive thinking. The reflective session will centre on the conceptual stage of the design problem, where respondents will be presented with an ill-defined problem to solve. Cross (2006) argues that the multi-step designing activity is controlled by the designer's decisions that are driven by their perceptions. This action is the perfect match to Schön's reflection-in-action paradigm, one of the problem-solving paradigms previously identified by Doorst and Dikjuis (1995). The reflective session is presented as the theme "Future Workspace for (Industrial) Designer in The Year 2050". In the in-depth interview, this discussion theme will be presented as the last part of the interview, where respondents will be asked to talk through how they envision the workspace concept.

Meanwhile, in the Focus Group research, the group of participants for each session is presented with a short warm-up sketching session with the same topic. In both data collection methods, time pressure is employed. Respondents are presented with it in an adhoc manner, without providing preparation time for deliberation. Finucane, Alhakami, Slovic and Johnson (2000).

Most time-pressure research has examined how cognitive processes and outcomes change because of the minimization of cognitive effort. The same concept is further discussed by Jones (2015). Despite the challenges of reflection-in-action as an objective observation process, there is value for its approach, especially in the construction of reason. In psychology, the concept of negative emotional valance is an excellent condition for encouraging emotive or less conscious reasoning, synonymous with an intuiting mode of thinking.

\subsection{Findings}

\subsection{In-Depth interview}

The in-depth interview is designed to collect data from two data sources; senior-level practising designer and expert-level practising designer. This activity will gather a rich narrative of actual practising designers that will be triangulated with the findings from the focus group discussion of novice designers. The structure of the interview design is adapted from the existing known measurement of intuition: Types of Intuition Scale (TIntS) developed by Pretz and Totz (2007) to measure three identified types of intuition; holistic, inferential, and affective. These empirical studies have contributed to various measurements conducted as quantitative analysis in other fields.

Table 2. In-Depth Interview Guideline

\begin{tabular}{|c|c|c|}
\hline Session & Inquiry guide & Guiding Keyword \\
\hline Section A: & Q1.1 Introduce yourself and years of working experience in the design field & - \\
\hline Background & & \\
\hline $\begin{array}{l}\text { The general } \\
\text { demographic profile } \\
\text { information will be } \\
\text { collected from the }\end{array}$ & $\begin{array}{l}\text { Q2.1 Summarize your understanding of what a typical design process is. } \\
\text { Q.2.2 At which point in your practice do you make decisions? } \\
\text { Probe: } \\
\text { Q2a How do you decide on which concept to proceed with? } \\
\text { Q2b was there a limitation? Factors that delayed process? }\end{array}$ & \\
\hline $\begin{array}{l}\text { Curriculum Vitae } \\
\text { provided by the } \\
\text { respondent. }\end{array}$ & $\begin{array}{l}\text { Q3.1 Talk about one of your greatest achievements in this field. } \\
\text { Probe: } \\
\text { Q3b What was the brief about? } \\
\text { Q3b talk about how the idea was conceived. }\end{array}$ & $\begin{array}{l}\text { emotion, heart, } \\
\text { feelings }\end{array}$ \\
\hline \multirow[t]{2}{*}{ Section B } & $\begin{array}{l}\text { Q4.1 Can you share an experience where you had to work on a problem-solving type of } \\
\text { design project. } \\
\text { Q4.2 Would you consider yourself a designer who works more with the hunches or with } \\
\text { the logic? Give a ratio percentage of hunches vs logic? Why do you say you are more } \\
\text { hunch-driven/ logic-driven? } \\
\text { Probe: } \\
\text { What motivates you to work on it? }\end{array}$ & $\begin{array}{l}\text { logic, Theories, Facts, } \\
\text { hunches }\end{array}$ \\
\hline & $\begin{array}{l}\text { Q5.1 Can you share an experience where you had to work on a futuristic-type project? } \\
\text { Probe: } \\
\text { Q5a How did you carry out the project? } \\
\text { Q5b How do you decide on the relevance of the information that you gathered/ had? } \\
\text { Q5c In your opinion, what is the optimum environment that would encourage better } \\
\text { concept ideation by designers? }\end{array}$ & $\begin{array}{l}\text { abstract thinking } \\
\text { Big ideas, big picture, }\end{array}$ \\
\hline Section C & $\begin{array}{l}\text { Q6.1 Within } 5 \text { to } 10 \text { minutes, talk us through your concept for the following topic: } \\
\text { "FUTURE WORKSPACE FOR (INDUSTRIAL) DESIGNER IN THE YEAR 2050" } \\
\text { Probe: } \\
\text { Q6a Talk about the concept of the idea. }\end{array}$ & \\
\hline
\end{tabular}




Q6b Where did the concept come from?
Q6c In what way do you think this idea will come true?
Q6d How will you defend this idea if it were to be presented to get the idea approved for
further development.
adapted from Types of Intuition Scale (Pretz and Totz, 2007)

\subsection{Focus Group Discussion}

The focus group research is designed as a controlled experiment set up with two modes of data gathering within a session. The experiment set-up has been previously discussed extensively to justify the set-up as an experiment. The dual-mode set-up is interconnected in that participants will begin with individual reflective sketching on "FUTURE WORKSPACE FOR (INDUSTRIAL) DESIGNER IN THE YEAR 2050" which is the same title prepared for the in-depth interview session. Just as in the in-depth interview case, participants in the focus group will not be allowed time for contemplation. Instead, it will be presented as a time-restricted sketching activity. The result of the warm-up in Mode 1, which is the concept on sketches, will be carried over to Mode 2, comprising of 3 subsessions. Sub session 1 requires sharing of concepts verbally with other participants in the group. Listeners will not verbalize their feedback immediately. Instead, the feedback is captured as written notes in the provided booklet. Room for feedback with individual defence will occur at sub-session 2. Finally, at sub-session 3, participants will be guided through a consensus-building exercise to work as a unit to agree on the best concepts from amongst the previously shared concept.
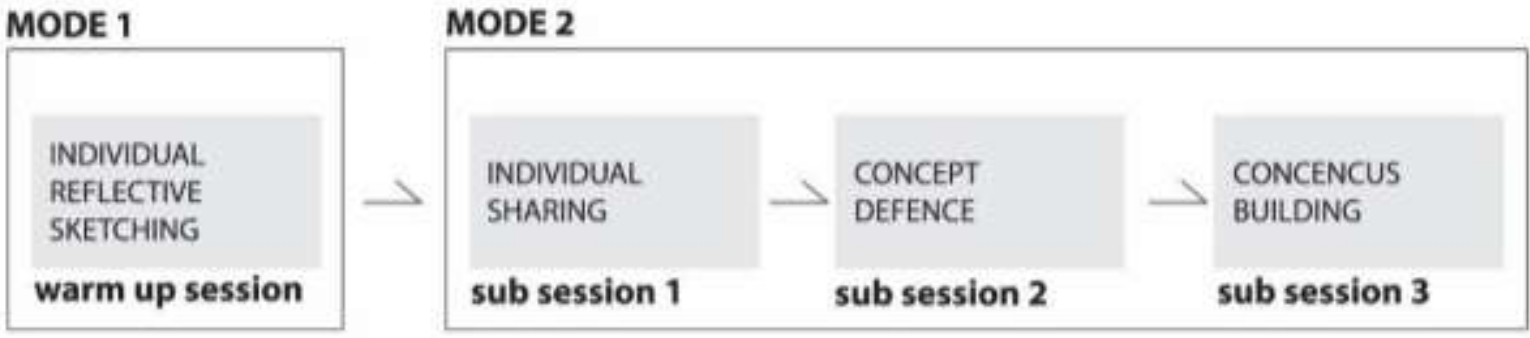

Fig. 1: Illustration Focus Group as a controlled experiment set up

Table 3. Moderator's Guideline for Focus Group Discussion

\begin{tabular}{|c|c|c|}
\hline Session & Inquiry guide & Guiding Keyword \\
\hline $\begin{array}{l}\text { Mode 1; Individual } \\
\text { Reflective Sketching }\end{array}$ & $\begin{array}{l}\text { Guide participants to the individual station } \\
\text { Topic sheets: "FUTURE WORKSPACE FOR (INDUSTRIAL) DESIGNER IN THE YEAR } \\
\text { 2050" }\end{array}$ & $\begin{array}{l}\text { Eight work station, } \\
\text { four cameras, topic }\end{array}$ \\
\hline $\begin{array}{l}\text { Mode 2; } \\
\text { Sub Session } 1 \\
\text { Individual Sharing }\end{array}$ & $\begin{array}{l}\text { For this session, we will go round the table to allow everyone to share their concept } \\
\text { ideation from the warm-up session. } \\
\text { Kindly show your sketch and describe your views on } \\
\text { "FUTURE WORKSPACE FOR MALAYSIAN INDUSTRIAL DESIGNER IN THE YEAR } \\
2050 \text { " } \\
\text { As you listened to each presentation, please fill in the form in the booklet in front of you. }\end{array}$ & $\begin{array}{l}\text { Participant } \\
\text { Booklet }\end{array}$ \\
\hline $\begin{array}{l}\text { Mode 2; } \\
\text { Sub-Session 2: } \\
\text { Concept Defence }\end{array}$ & $\begin{array}{l}\text { In sub-session } 2 \text {. We will go round the table again, but this time, fellow participants will } \\
\text { share what they disagree on and the presenting participant will need to defend/ clarify } \\
\text { his/her concept. } \\
\text { If you need to take note of feedback from others, write in the note section. }\end{array}$ & $\begin{array}{l}\text { Participant } \\
\text { Booklet }\end{array}$ \\
\hline \multirow[t]{2}{*}{$\begin{array}{l}\text { Mode 2; } \\
\text { Sub-session 3: } \\
\text { Consensus Building }\end{array}$} & $\begin{array}{l}\text { Each participant will have different coloured post-its. } \\
\text { Based on all that was heard and discussed, write the most the best future workplace } \\
\text { scenario in the form of one descriptive sentence based on the categories that I will read } \\
\text { out. }\end{array}$ & Post-it notes \\
\hline & $\begin{array}{l}\text { Next, let us look at these post its and decide on one best for every category. } \\
\text { The point here is not to argue but to work towards the best concept. }\end{array}$ & Framework Sheet \\
\hline
\end{tabular}

\subsection{Results and Discussion}

This section will not report on the findings of the inquiry as it relates to the subject matter. Instead, the discussion focuses on the pilot test result on four in-depth interviews developed through the efficiency and effectiveness of the two modes of inquiry of the pilot test on four in-depth interview and one session of the focus group discussion. The review is based on the feedback from a short follow up interview with respondents and researchers notes on the session.

\subsection{Discussion on In-Depth Interview}

The first four interviews were conducted, followed by a short feedback session with the interviewee to assess the clarity of the enquiries. The estimated in-depth interview 1 hour 15-minute duration time for an interview session could not be met. The questions required in reflection and detailed storytelling on the part of the respondents. This took some time. The duration of audio files are as follows; Pilot 
Interview $1=1: 43: 58$ (1:19:48 + 0:24:10), Pilot Interview $2=1: 11: 54$ (0:55:46 + 0:15:58), Pilot Interview $3=1: 03: 07$ and Pilot Interview $4=1: 18: 42$. Pilot interview 1 took the longest because, as the first of the preliminary interview, the researcher attempts to get familiar with the question guide whilst adjusting to the dynamics of the interview flow. This explains the outlier nature of the duration compared to the following three. The duration of the following three interviews averaged at 1:11:12. However, this does not consider the allocated time spent on producing sketches for section C, Graphic Elicitation \& Reflection. The initial time of 5 minutes was increased to a flexible ' 5 to 10 minutes to allow for more reflective thinking and detailing by respondents. In summary, the estimated interview time is reset at $1 \mathrm{hr} 30$ minutes to allow for a less rushed interview session.

Besides that, additional time was added to allow for more detailing and reflective sketches. One of the preliminary respondents was not comfortable sketching, instead resorted to diagramming and verbalizing his thoughts. Although sketching is preferred due to nature or designers being very visual people, diagramming, other forms of visualization on paper or detailed narrative of the idea should still be allowed. The study wishes to capture the richness of the respondent's experience, which should not be hindered from the discomfort of being put on the spot.

\subsection{Discussion on Focus Group}

The key findings from the preliminary first session of the pilot focus group discussion did not meet the duration time frame allotted for sub-session 1 and sub-session 2. Initially, the sessions were conducted as one part, in an open debate environment. However, the constant non-moderated feedback made individual presentations longer as comments constantly disrupted it. The following guideline (Table 4) is an improved scheme for the focus group session.

\begin{tabular}{|c|c|c|c|}
\hline Session breakdown & Activity description & Duration (min) & Time (am) \\
\hline Refreshments \& registration & $\begin{array}{l}\text { Arrival, registration, consent form signing, token award and acceptance form signing and } \\
\text { refreshment }\end{array}$ & 30 & 08.00 \\
\hline Pre-Introduction & $\begin{array}{l}\text { Briefing on the project's objectives, the aims/ programme for the session, participant } \\
\text { number and seating arrangement. Practical issues: alert to video recording, feedback and } \\
\text { questions. }\end{array}$ & 5 & 08.30 \\
\hline $\begin{array}{l}\text { Warm-up session } \\
\text { Individual reflective sketching }\end{array}$ & $\begin{array}{l}\text { Participants are guided to the individual station with a visual recording device set up, } \\
\text { provided with topic sheets, timer and sketching materials. } \\
\text { Participants are led to the main discussion table }\end{array}$ & 10 & 08.35 \\
\hline Introduction & $\begin{array}{l}\text { Explanation on the function of the post-its notes and the booklet. Briefing on focus group } \\
\text { flow that is divided into three sub-session; Sub-Session 1: Individual Sharing, Sub-Session } \\
\text { 2: Concept Defence, Sub-Session 3: Consensus Building }\end{array}$ & 5 & 08.45 \\
\hline Sub-Session 1 & $\begin{array}{l}\text { Moderated round the table presentation to allow participants to share their concept } \\
\text { ideation from the warm-up session. Participants present individual sketches on their views } \\
\text { of FUTURE WORKSPACE FOR MALAYSIAN INDUSTRIAL DESIGNER IN THE YEAR } \\
\text { 2050. Other participants will fill in their feedback in the forms in the booklet provided. }\end{array}$ & 15 & 08.50 \\
\hline $\begin{array}{l}\text { Sub-Session 2: Concept } \\
\text { Defence }\end{array}$ & $\begin{array}{l}\text { The second round on moderated round the table discussion by fellow participants to share } \\
\text { comments/ views. Particular participant will defend/ clarify his/her concept. Comments are } \\
\text { captured in the note section of the booklet. }\end{array}$ & 30 & 09.05 \\
\hline Consensus Building & $\begin{array}{l}\text { Participants will have a different coloured post its. } \\
\text { Based on all that was heard and discussed, individuals will write the best future workplace } \\
\text { scenario in the form of one descriptive sentence based on the categories that are found on } \\
\text { the provided discussion template. }\end{array}$ & 10 & 09.35 \\
\hline & $\begin{array}{l}\text { As a group, participants look through these post its and decide on one best for every } \\
\text { category. Participants are moderated not to argue but to build consensus to work towards } \\
\text { the best concept. }\end{array}$ & 10 & 09.45 \\
\hline Ending Session & $\begin{array}{l}\text { Show gratitude for participation and a reminder to } \\
\text { refrain from discussing with anyone after the session ends hoping that participants of the } \\
\text { next session will be able to go through the study with the same minimal expectation. }\end{array}$ & 5 & 09.55 \\
\hline \multicolumn{4}{|l|}{ Session Ends } \\
\hline
\end{tabular}

\subsection{Conclusions}

In conclusion, the feedback from the pilot test has resulted in only structural changes on the flow of the interview and focus group discussion for more efficient data collection. Except for the change of visual to verbal elicitation of concept on the design practitioners, the content collected can still be included as overall usable data.

\section{Acknowledgements}

The authors gratefully acknowledge that the research is supported by Universiti Teknologi MARA, Grant number: 600-IRMI/MYRA 5/3/REI (002/2018) and Research Management Institute of Universiti Teknologi MARA for managing the grant. 


\section{References}

Abidin, S. Z., Bjelland, H. V., \& Øritsland, T. A. (2008). The embodied mind in relation to thinking about form development. In Proceedings of NordDesign 2008 Conference (pp. 265-274).

Abidin, S.Z., Christoforidou, D., \& Liem, A. (2009). Thinking and re-thinking verbal protocol analysis in design research. In DS 58-2: Proceedings of ICED 09, the 17th International Conference on Engineering Design (Vol. 2, pp. 1-12)

Abidin, S. Z., Othman, A., Shamsuddin, Z., Samsudin, Z., Hassan, H., \& Mohamed, W. A. W. (2016). Identifying sequence maps or locus to represent the genetic structure or genome standard of styling DNA in automotive design. Advances on Mechanics, Design Engineering and Manufacturing, 1159-1166. doi:10.1007/978-3-319-457819116

Abidin, S.Z., Warell, A., \& Liem, A. (2011). The significance of form elements: A study of representational content of design sketches. In Proceedings of the DESIRE'11 Conference on Creativity and Innovation in Design (pp. 21-30). DOI: 10.1145/2079216.2079219

Alós-Ferrer, C. and Hügelschäfer, S., 2016. Faith in Intuition And Cognitive Reflection. Journal of Behavioral and Experimental Economics, 64, pp.61-70.

Bohart, A.C., 1999. Intuition And Creativity In Psychotherapy. Journal of Constructivist Psychology, 12(4), pp.287-311.

Chumiran, M.H., Abidin, S. Z., \& Mohamed Kamil, M. J. (2020). Pre-Post Observation Research Fosters a Preliminary Study in Product Form Identity. In L., Buck, E. Bohemia, \& H. Grierson, Proceedings of the 22nd International Conference on Engineering and Product Design Education, E and PDE 2020 Institution of Engineering Designers, The Design Society.

Çizgen, G. and Ulusu Uraz, T., 2019. The Unknown Position of Intuition in Design Activity. The Design Journal, 22(3), pp.257-276.

Cross, N., 2001. Designerly ways of knowing: Design Discipline Versus Design Science. Design issues, 17(3), pp.49-55.

Cross, N., 2006. Understanding design cognition. Designerly Ways of Knowing, pp.77-93

Schon, D., 1983. The Reflective Practitioner (London, Temple Smith).

Dolan, R.J., 2002. Emotion, cognition, and behavior. science, 298(5596), pp.1191-1194.

Dorst, K. and Dijkhuis, J., 1995. Comparing Paradigms For Describing Design Activity. Design studies, 16(2), pp.261-274.

Dörfler, V. and Stierand, M., 2016, August. Enhancing intuition: focusing on indirect ways. In 76th Annual Meeting of the Academy of Management.

Eling, K., Griffin, A. and Langerak, F., 2014. Using Intuition In Fuzzy Front-End Decision-Making: A conceptual framework. Journal of Product Innovation Management, 31(5), pp.956-972.

Finucane, M.L., Alhakami, A., Slovic, P. and Johnson, S.M., 2000. The Affect Heuristic In Judgments Of Risks And Benefits. Journal of Behavioral Decision Making, 13(1), pp.1-17.

Gasparatou, R., 2010. Experimental appeals to intuition. Crítica: Revista Hispanoamericana de Filosofía, pp.31-50.

Gore, J. and Sadler-Smith, E., 2011. Unpacking intuition: A process and outcome framework. Review of General Psychology, 15(4), pp.304-316.

Golafshani, N., 2003. Understanding Reliability and Validity in Qualitative Research. The Qualitative Report, 8(4), pp.597-606.

Jones, D., 2015. Reflection-in-action and motivated reasoning

Lee, T.Y. and Chien, C.S., 2018. Connecting Creativity with Intuitive Knowing. Canadian Social Science, 14(2), pp.16-26.

Liem, A., Abidin, S. and Warell, A., 2009, October. Designers' perceptions of typical characteristics of form treatment in automobile styling. In 5th International Workshop on Design \& Semantics of Form and Movement, DesForm.

Liao, S.M., 2008. A defense of intuitions. Philosophical Studies, 140(2), pp.247-262.

Mohamed Kamil, M. J., \& Abidin, S.Z. (2015). Unconscious interaction between human cognition and behavior in everyday product: A study of product form entities through free hand sketching using the design syntactic analysis. Proceedings of the 17th International Conference on Engineering and Product Design Education (E\&PDE15), Great Expectations: Design Teaching, Research \& Enterprise, Loughborough, UK, 03-04.09.2015 (p.369-374)

Mohamed Kamil, M. J., Abidin, S.Z., \& Hasdinor Hassan, O. H. (2018). The investigation of designers' Reflective Practice Activity Using Verbal Protocol Analysis, Proceedings of the 20th International Conference on Engineering and Product Design Education (E\&PDE 2018), Dyson School of Engineering, Imperial College, London. 6th - 7th September 2018, (p. 363-368)

Ness, L.R., 2015. Are We There Yet? Data saturation in qualitative research.

Pretz, J.E., Brookings, J.B., Carlson, L.A., Humbert, T.K., Roy, M., Jones, M. and Memmert, D., 2014. Development and Validation of a New Measure of Intuition: The Types Of Intuition Scale. Journal of Behavioral Decision Making, 27(5), pp.454-467.

Sinclair, M., 2011. An Integrated Framework of Intuition. Handbook of intuition research, 1, pp.3-16. 
Stierand, M. and Dörfler, V., 2016. The role of intuition in the creative process of expert chefs. The Journal of Creative Behavior, 50(3), pp.178-185.

Pretz, J.E. and Totz, K.S., 2007. Measuring Individual Differences in Affective, Heuristic, and Holistic Intuition. Personality and Individual Differences, 43(5), pp.12471257.

Popovic, V., 2004. Expertise Development in Product Design-Strategic and Domain-Specific Knowledge Connections. Design Studies, 25(5), pp.527-545.

Smith, B. and McGannon, K.R., 2018. Developing Rigor in Qualitative Research: Problems and Opportunities within Sport and Exercise Psychology. International Review of Sport and Exercise Psychology, 11(1), pp.101-121.

Wang, Y., Highhouse, S., Lake, C.J., Petersen, N.L. and Rada, T.B., 2017. Meta-Analytic Investigations of the Relation between Intuition and Analysis. Journal of Behavioral Decision Making, 30(1), pp.15-25.

Welling, H., 2005. The Intuitive Process: The Case of Psychotherapy. Journal of Psychotherapy Integration, 15(1), p.19.

Wolfe, C.J., Christensen, B.E. and Vandervelde, S.D., 2019. Intuition versus Analytical Thinking and Impairment Testing. Contemporary Accounting Research.

Zainal Abidin, S., Anwar, R., \& Rahim, W.N. (2020). The Presence of Fibonacci Sequence in Malaysia Keris Design Related to Elements of Art and Principles of Design Environment-Behaviour Proceedings Journal, 5(SI3), 141-147.

Zainal Abidin, S., Sigurjónsson, J., Liem, A., \& Keitsch, M. (2008). On the role of formgiving in design. In DS 46: Proceedings of E and PDE 2008, the 10th International Conference on Engineering and Product Design Education. 